\title{
SIGHTINGS OF NON-NATIVE RED-EARED SLIDERS IN WASCANA MARSH, REGINA, SASKATCHEWAN
}

Kelsey A. Marchand ${ }^{1}$, Christopher M. Somers ${ }^{1}$, and Ray G. Poulin ${ }^{2}$ ${ }^{1}$ Department of Biology, University of Regina, Regina,

Saskatchewan; email: kelseymarchand@gmail.com, chris.somers@ uregina.ca

${ }^{2}$ Royal Saskatchewan Museum, Regina, Saskatchewan

Two turtle species are native to Saskatchewan, the snapping turtle (Chelydra serpentina) and the western painted turtle (Chrysemys picta bellii). The snapping turtle is primarily found in the southeast corner of Saskatchewan, whereas the western painted turtle is more widespread reaching areas as far north as the Saskatchewan River and Duck Mountain. ${ }^{1}$ Neither species is listed as at risk of extinction, however little is known about the ecology of turtles in Saskatchewan. On 10 July 2015, a red-eared slider (Trachemys scripta elegans) was found swimming in Wascana Marsh, Regina, Saskatchewan. As of September 2015, there have been six confirmed sightings of redeared sliders in Wascana Marsh, Regina: two captures, one shell from a dead individual, and three visual observations. The red-eared slider is not native to Canada; it is naturally found in the central and southeastern United States, but has become an invasive species in many ecosystems. Sliders are commonly found in the turtle pet trade, and they enter natural aquatic ecosystems when people release unwanted pets into the wild. As a result, red-eared sliders have been introduced on all continents except Antarctica. ${ }^{2}$ Their introduced populations compete with native turtles for resources, and introduce novel diseases to native populations. ${ }^{2,3}$ Sliders can be distinguished from the native western painted turtle by the "red ears" found on either side of their head (Fig. 1). Western painted turtles do not have this red patch, but rather yellow stripes surrounding the head (Fig. 2). The plastron can also be distinguished between the two species; the red-eared slider has a yellow to cream colored plastron with brown or black markings on each of the scutes (Fig. 3), whereas the western painted turtle has a red plastron with a black and yellow design that connects along the seams of each of the scutes (Fig. 4). Red-eared sliders may represent a novel threat to western painted turtles in Saskatchewan, which 
already face many challenges from climate and anthropogenic changes to watersheds.

1. Secoy D (2006) The encyclopedia of Saskatchewan: reptiles. Available from http:// esask.uregina.ca/entry/reptiles. html [Accessed 1 September 2015].

2. Ernst $\mathrm{CH}$ and Lovich JE (2009) Turtles of the United States and Canada, $2^{\text {nd }}$ edition. The John Hopkins University Press, Baltimore, Maryland.

3. Cadi A and Joly P (2003) Competition for basking places between the endangered European pond turtle (Emys orbicularis galloitalica ) and the introduced red-eared slider (Trachemys scripta elegans). Canadian Journal of Zoology . 81: 1392-1398.

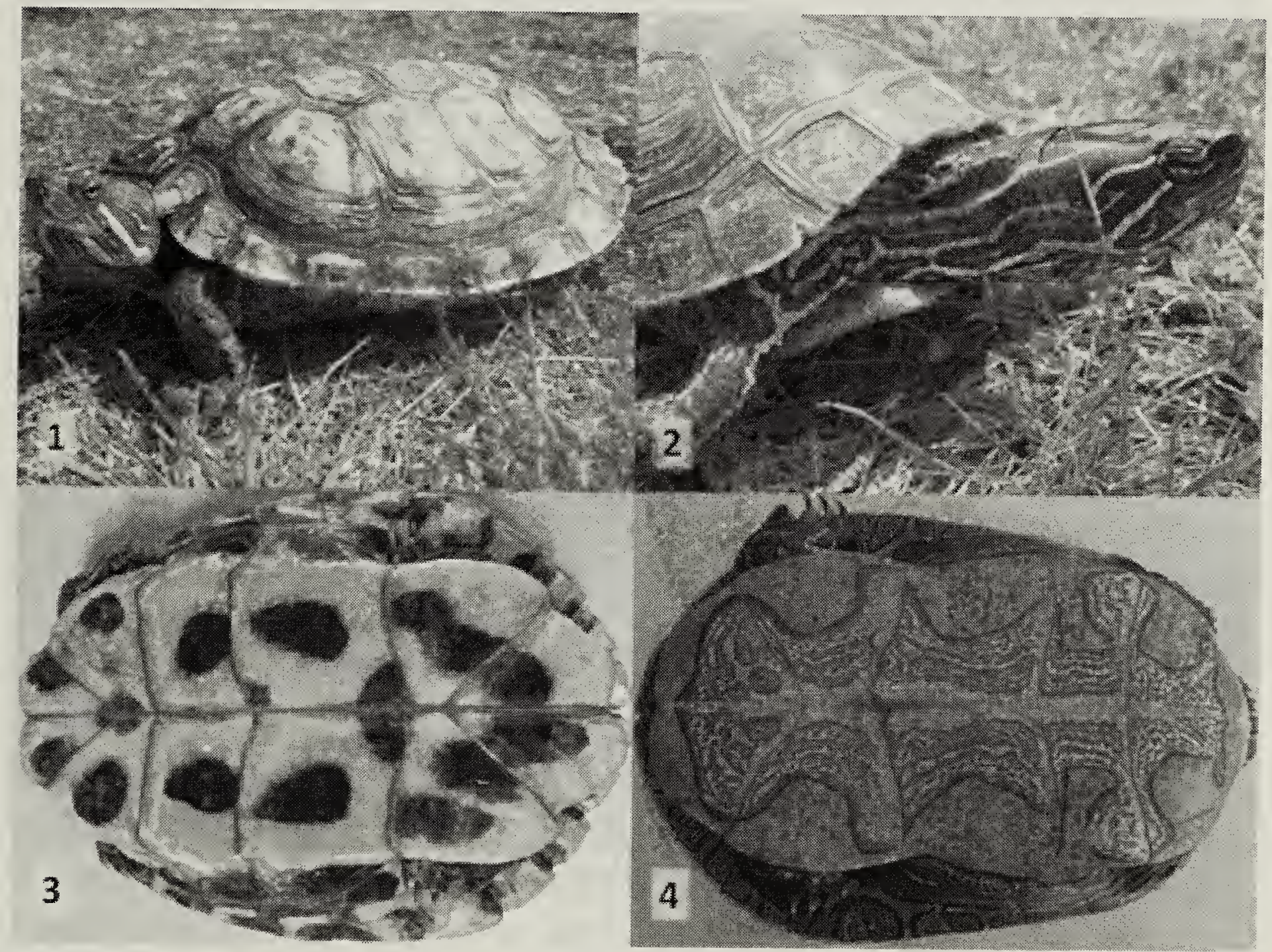

Figures 1-4

(See inside front cover for colour image) 